\title{
Şanlıurfa İlinde Hipertansiyon Tanısı Almış Hasta Profilinin İncelenmesi
}

\author{
İbrahim Dağ®, Selma Kahraman®
}

Harran Üniversitesi, Hemşirelik, Şanlıurfa, Türkiye

İbrahim Dağ, Arş. Gör. Selma Kahraman, Yrd. Doç.Dr.

Iletişim:

Selma Kahraman

Harran Üniversitesi, Hemşirelik, Şanlıurfa, Türkiye

Tel: +905447713257

E-Posta: skahraman1308@gmail.com

Gönderilme Tarihi : 16 Temmuz 2018

Revizyon Tarihi : : 11 Eylül 2018

Kabul Tarihi : $\quad 12$ Eylül 2018
ÖZET

Amaç: Bu araştırma, Şanlıurfa ili merkez ilçelerinde yaşayan hipertansiyon tanısı almış hasta profilini ortaya çıkarmak amacıyla yapılmıştır.

Çalışma Planı: Tanımlayııı tipteki bu araştırmanın örneklemini Şanlıurfa Merkez hastaneleri dahiliye ve kardiyoloji kliniklerine başvuran 320 hipertansiyon tanılı kişi oluşturmuştur. Veriler, hasta bilgi toplama formu kullanılarak toplanmıştır. Veriler SPSS 16.0 paket programı ile tanımlayıc istatistik, Ki-Kare Testi, Mann Whitney U Testi ve Kruskal-Wallis Testi ile değerlendirilmiştir.

Bulgular: Hipertansiyon tanısı almış hastaların yaş ortalamasının $61,48 \pm 2,19, \% 51,9^{\prime}$ unun (166) ise erkekler olduğu saptanmıştır. Hastaların \%93,1'i evli olup, \%45,9'unun okuryazar olmadığı tespit edilmiştir. Hastaların \%41,6'sının (133) beden kitle indeksi 25-29,99 (toplu-hafif şişman) arasında olduğu belirtilmiştir. Hastaların ortalama sistolik kan basıncı değeri 153,42 $\pm 24,15$, diyastolik kan basıncı değeri $96,12 \pm 19,37$ çıkmıştır. Kadınlarda sistolik kan basıncı ortancası 157,77 iken, erkeklerde 163,04'tür (p>0,05). 45 yaşından küçüklerde sistolik kan basıncı ortancası 199,94 iken, yaşı 75 ve üzeri olanlarda 132,59 'dur ( $p<0,05)$. Eğitim durumu ve gelir durumu yükseldikçe, hastaların kan basıncı ortanca değerleri de yükselmiștir $(p<0,05)$. 0kuryazar olmayan hastaların $\% 44,7$ 'sinin hipertansiyon hakkında bilgisi varken, bu oran ilköğretim mezunu ve üzeri kısımda $\% 45,9$ 'dur $(p>0,05)$. Hipertansiyon hakkında bilgi durumunun yaş arttıkça $(p>0,05)$ ve çalışmayanlarda daha yüksek $(p>0,05)$ olduğu saptanmıştır.

Sonuç ve Öneriler: Bu çalışma Şanlıurfa'da hipertansiyonun yaygın bir sorun olduğunun, kan basıncı değerlerinin oldukça yüksek olduğu, bu sorunun yeterince farkında olunmadığının ve hipertansiyona yönelik koruyucu, önlenebilir hizmetlerin yetersiz yapııdığııın hatıılatılması açııından önemlidir. Bu nedenle tüm yaş gruplarına yönelik korunma ve önleme programlarının uygulanmasına önem verilmelidir.

Anahtar sözcükler: Şanlıurfa, hipertansiyon, hemşirelik

\section{DETERMINATION OF THE HYPERTENSION PATIENTS' PROFILE'S IN SANLIURFA}

ABSTRACT

Objective: This study was carried out to investigate the profiles of patients who live in the city center of şanlıurfa and were diagnosed with hypertension.

Study Design: The sample of this descriptive study consisted of 320 hypertensive patients who visited the internal medicine and cardiology clinics in Şanlıurfa Central Hospital. The data were collected using the patient data collection form. Data were analyzed by descriptive statistics, Chi-square test, Mann Whitney U test and Kruskal-Wallis test with SPSS 16.0 package program.

Findings: The mean age of the patients diagnosed with hypertension was $61,48 \pm 2,19$ and $\% 51,9(166)$ were males. $\% 93,1$ of the patients were married and $\% 45,9$ were illiterate. $\% 41,6$ (133) of the patients were found to have a body mass index (BMI), 25-29,99 (mass-fat). The mean systolic blood pressure of the patients was 153,42 $\pm 24,15$ and the diastolic blood pressure was $96,12 \pm 19,37$. The median systolic blood pressure was 157,77 in females and 163,04 in males ( $p>0,05)$. The median systolic blood pressure was 199,94 in those younger than 45 years, while it was $132,59(p<0,05)$ in those older than 75 . As the education status and the income status increased, the median blood pressure values also increased $(p<0,05)$.

$44,7 \%$ of literate patients had knowledge about hypertension, this rate was $45,9 \%$ for primary school graduates and above $(p>0,05)$. Hypertension status was found to be higher $(p>0,05)$ and higher $(p>0,05)$.

Conclusions and Recommendations: This study is important because it shows that hypertension is a common problem in Şanlıurfa, blood pressure values are very high among the population, and it is important to remember that this problem is not well understood and is not adequately treated. For this reason, importance should be attached to the implementation of prevention and prevention programs for all age groups.

Keywords: Şanlıurfa, hypertension, nursing 


\section{Problemin tanımı ve önemi}

Dünyada beklenen yaşam süresinin ve sağlıksız yaşam alışkanlıklarının artışı ile birlikte, kronik hastalıkların da arttığı görülmektedir (1). Kronik hastalıklardan küresel ölçekte bir numaralı ölüm sebebini koroner kalp hastalıkları olduğu bildirilmektedir (2). Ülkemizde de aynı durum gözükmekte, ölüm nedenleri arasında, koroner kalp hastalığına bağlı ölümler birinci sırada yer almaktadır. Koroner kalp hastalıkları içinde en çok görülen ve nedeni olan hastalık hipertansiyondur (3). Koroner kalp hastalıklarına en sık neden olan hipertansiyon, koroner kalp hastalıkların önlenebilir önemli bir nedenidir. Tedavi edilmezse koroner, serebral ve renal vasküler hastalıklar için majör risk faktörü olup, yaşam süresini kısaltmaktadır (4-6). Hipertansiyon, arteryel kan basıncının sürekli olarak yüksek olması durumudur. Ayrıca morbidite ve mortalite nedeni olan önemli bir halk sağlığı sorunudur (7).

Dünyada kardiyovasküler nedenlerle her yıl yaklaşık 17 milyon kişi ölmektedir. Hipertansiyon komplikasyonları, bu ölümlerden 9,4 milyonunun nedenidir. Kalp hastalığına bağlı ölümlerin $\% 45$ 'i, inmeye bağlı ölümlerin $\% 51$ 'i yüksek kan basıncına bağlıdır (3). 2000 yılı itibariyle dünyada erişkin nüfusun $\% 26,4$ 'ünün hipertansiyonu olduğu ve bu oranın 2025 yılında \%29,2'ye çıkacağı öngörülmüştür. Bir diğer deyişle, halen 972 milyon insan hipertansiyon hastasıdır ve 15 yıl sonra bu rakam 1,5 milyarı aşacaktır (8). Türkiye'de ise; 2013 kronik hastalıklar raporuna göre, ölçümle hipertansiyon saptanan kişilerin yüzde $48^{\prime} i$ aynı zamanda doktor tanısına dayalı hipertansiyon bildirmiştir; bu oran erkeklerde yüzde 36 , kadınlarda yüzde $58^{\prime}$ dir. Öykü ve ölçümle elde edilen veriye göre araştırmada bulunan toplam hipertansiyon prevalansı yüzde 24 olup; erkeklerde yüzde 21 , kadınlarda yüzde 26 'dır. 60 yaş ve üzeri nüfusta ise bu oranların $\% 63,9$ ve $\% 66,7$ 'ye kadar yükseldiği belirlenmiştir $(9,10)$. Dünyada olduğu gibi ülkemizde de, yüksek bir prevalansa sahip olan hipertansiyonun hastalarının profilini belirlemek, durumuna yönelik hemşirelik bakımını yapmakla, hipertansiyonun komplikasyonlarını azaltacak ve böylece hastanın yaşam kalitesini artıracaktır.

Hipertansiyon hastalığı ayrıca önlenebilir, korunabilir olmasından dolayı bu konuda yapılacak sağlık hizmetleri önemli bir noktaya ulaşmıştır. Hipertansiyon hastalığının önlenebilir, korunabilir olmasında hasta profilini belirlemekte önemli bir konudur. Bu konuda en önemli sorumluluk hemşirelere düşmektedir. İnsanların sağlıklarında herhangi bir sapma olduğunda, yaşamdan aldıkları doyum azalabilir. Bu noktada hemşirenin rolü ve amacl; bireye kendi bakımını yapar hale gelinceye dek yardımcı olmak; en kısa zamanda bireyin kendi bakımını üstlenmesini, gereksinimlerini karşılayabilmesini sağlamak ve tüm bu süreçlerde yaşam doyumunu en üst düzeye çıkartmaktır. Hipertansiyon hastasının bakımında hemşirenin amacı, yan etkisiz ve az maliyetle kan basıncını düşürme ve kontrol altında tutma üzerine odaklanmalıdır (11). Bu amaca ulaşmak için hemşire, hastanın ilaçları önerildiği gibi kullanması, önerilen yaşam tarzı değişikliklerini gerçekleştirmesi ve hastalığın sürecini izleme, ilaçların ya da hastalığın istenmeyen durumlarının değerlendirilmesi için düzenli sağlık kontrollerine gelmesi konusunda hasta ve ailesini desteklemeli ve gerekli eğitimi vermelidir.

Araştırmanın amacı: Şanlıurfa ili merkez ilçelerinde yaşayan hipertansiyon tanısı almış hastaların profilini ortaya çıkarmak, bu konuda literatürü artırmak ve araştırmalara teşvik etmektir.

\section{Gereç ve yöntem}

Araştırmanın şekli: Araştırma; tanımlayıcı olarak hastanelerin son bir yıllık hasta kayıtları taranarak planlanmıştır.

Araştırmanın yapıldığı yer ve tarih; Araştırmanın evrenini, Şanlıurfa merkez ilçelerinde bulunan 3 hastanede yer alan dahiliye ve kardiyoloji polikliniklerinden, son 1 yıl içinde (7 Temmuz 2014 - 7 Temmuz 2015 tarihleri arasında) hipertansiyon tanısı almış hastalar oluşturmuştur.

Araştırmanın evreni ve örneklemi: Hastane kayıtlarına göre; son 1 yıl içerisinde Harran Üniversitesi Araştırma ve Uygulama Hastanesi'nde 3547 hasta, Mehmet Akif İnan Eğitim ve Araştırma Hastanesi'nde 21700 hasta, Balıklıgöl Devlet Hastanesi'nde 18932 hasta ve toplamda da 44179 hasta, hipertansiyon tanısı almış olarak kayda geçmiştir. Araştırmanın örneklem büyüklüğü ise, evreni bilinen örneklem formülüne göre, $a=0,05$ anlamlılık düzeyde ve $d=0.05$ örnekleme hatası ile $p=0,3, q=0,7$ sütununda minimun örneklem büyüklüğü 321 kişi hesaplanmıştır (12).

Bu verilere göre örneklem, Şanlıurfa merkeze genelleyebilmesi için tabakalı örneklem yöntemi kullanılmış olup, her hastaneden hipertansiyon tanısı almış hastalara ulaşılmıştır. Buna göre Harran Üniversitesi Araştırma ve Uygulama Hastanesi'nden 26 hastaya, Mehmet Akif İnan Eğitim ve Araştırma Hastanesi'nden 158 hastaya, Balıklıgöl Devlet Hastanesi'nden 136 hastaya ve toplamda da 320 hastaya ulaşılmıştır.

Araştırmanın örneklem kriterleri: Son bir yılda Hipertansiyon tanısı almış olmak, araştırmaya katılmaya gönüllü olmak ve iletişim problemi yaşamıyor ve kendini ifade edebiliyor olmaktır. 
Veri toplama araçları

Araştırmanın verileri; araştırmacı tarafından literatür ışığında ve uzman görüşü alınarak hazırlanmış olup, “Hasta Bilgi Toplama Formu”' kullanılarak toplanmıştır. 'Hasta Bilgi Toplama Formu' 40 sorudan oluşmaktadır. Bu form ile hastanın yaşı, cinsiyeti, eğitim durumu gibi demografik bilgilerin yanı sıra, ne kadar süredir hipertansiyon hastası olduğu, günlük kaç adet antihipertansif ilaç kullandığı, sigara, alkol, tuz, yağ, çay veya kahve kullanıp kullanmadığı ve fiziksel herhangi bir aktivite yapıp yapmadığına ilişkin veriler toplanmıştır.

\section{Araştırmanın uygulanması}

Araştırmaya başlamadan önce araştırmacı gerek polikliniklerde, gerekse kliniklerde sorumlu kişilerle görüşmüş ve araştırmanın planlaması yapılmıştır. Bu planlamaya göre araştırmacı hafta içi belirli saatler (genellikle poliklinik saatleri olan 9-16 saatleri) arasında poliklinik ve/veya servislerde bulunarak, örneklem kıstaslarına uygun hastaları tespit etmiştir.

Uygulama yapılacak her hastaya araştırmacı tarafından gerekli açıklamalar ve araştırma hakkında bilgi verildikten sonra kişinin onamı alınmıştır. Araştırmacı, hastayı klinikte kendi odasında, poliklinikte ise uygun bir odaya alarak yüz yüze görüşme yöntemiyle verileri toplamıştır. Görüşme süresi en az 8 dakika, en fazla 20 dakika sürmüştür. Görüşmeden sonra hastanın tansiyonu ölçülmüştür.

\section{Araştırmanın etik yönü}

Çalışmanın etik kurallar uygunluğu açısından, Harran Üniversitesi Etik Kurul Komisyonundan onay, Araştırma kapsamında bulunan tüm hastanelerden yazılı izin ve bireylerden onam alınmıştır.

\section{Verilerin değerlendirilmesi}

Verilerin değerlendirilmesinde SPSS (Statistical Package for the Social Sciences) for Windows 16.0 paket programında tanımlayıcı istatistik, analiz için Ki-Kare, Mann Whitney U Testi, Kruskal-Wallis Testleri kullanılmıştır. Bütün analizlerde \%95 güven aralığı kullanılmış olup, $p<0.05$ değerleri anlamlı olarak kabul edilmiştir.

\section{Bulgular}

Çalışmadaki hastaların sosyo-demografik özellikleri Tablo 1 'de belirtilmiştir. Araştırmaya katılan hipertansiyon tanısı almış bireylerin \%51,9'unun (166) erkek, \%49,4'ünün (158) 60-74 yaşları arasında, \%45,9'unun ise okuryazar olmadığı tespit edilmiştir. 320 bireyin \%93,1'i evli, \%41,6'sının (133) beden kitle indeksi (BKI), 25-29,99 (toplu-hafif şişman) arasında olduğu saptanmıştır. Hastaların \%97,2'sinin (311) herhangi bir sosyal güvencesi bulunmaktadır.
Tablo 2'de Hastaların \%74,4'ünün (238) hipertansiyon tanısı dışında, başka hastalıkları da olduğu görülmektedir. Bu hastalıkların \%24,7'sini kalp hastalıkları, \%13,8'ini diyabet, \%9,1'ini astım, \%5,6'sını akciğer hastalıkları

Tablo 1. Hastaların sosyo-demografik özellikleri

\begin{tabular}{|c|c|c|c|}
\hline Değişkenler n: 320 & & Sayı & Yüzdelik \\
\hline \multirow{4}{*}{$\begin{array}{l}\text { Yaş Ortalama } \\
61.48 \pm 2.19\end{array}$} & 45’ten küçük & 32 & 10 \\
\hline & 45 - 59 arası & 89 & 27,8 \\
\hline & $60-74$ arası & 158 & 49,4 \\
\hline & 75 ve üzeri & 41 & 12,8 \\
\hline \multirow[t]{2}{*}{ Cinsiyet } & Kadın & 154 & 48,1 \\
\hline & Erkek & 166 & 51,9 \\
\hline \multirow[t]{3}{*}{ Beden Kitle İndeksi } & 0 - 24.99 (normal) & 122 & 38,1 \\
\hline & $\begin{array}{c}25-29.99 \\
\text { (toplu-hafif şişman) }\end{array}$ & 133 & 41,6 \\
\hline & 30 ve üstü (obez) & 65 & 20,3 \\
\hline \multirow[t]{3}{*}{ Eğitim Durumu } & Okuryazar değil & 147 & 45,9 \\
\hline & Okuryazar & 78 & 24,4 \\
\hline & İlköğretim mezunu ve üzeri & 95 & 29,7 \\
\hline \multirow[t]{2}{*}{ Çalışma Durumu } & Çalışmıyor & 208 & 65 \\
\hline & Çalışıyor & 112 & 35 \\
\hline \multirow[t]{3}{*}{ Aylık Geliri } & Geliri yok & 120 & 37,5 \\
\hline & $1-1300 \mathrm{TL}$ & 121 & 37,8 \\
\hline & 1300 TL üzeri & 79 & 24,7 \\
\hline
\end{tabular}

Tablo 2. Hastaların hipertansiyon hastalığı ile ilgili durumları

\begin{tabular}{|c|c|c|c|}
\hline Değişkenler N: 320 & & Sayı & Yüzdelik \\
\hline \multirow{2}{*}{$\begin{array}{l}\text { Hipertansiyon dışında } \\
\text { başka hastalık varlığı * }\end{array}$} & Hayır & 82 & 25,6 \\
\hline & Evet & 238 & 74,4 \\
\hline \multirow{2}{*}{$\begin{array}{l}\text { Ailenizde hipertansiyon } \\
\text { varlığı* }\end{array}$} & Hayır & 112 & 35 \\
\hline & Evet & 208 & 65 \\
\hline \multirow{4}{*}{$\begin{array}{l}\text { Hipertansiyon tanısı } \\
\text { aldığı yaş }\end{array}$} & $21-36$ yaş & 26 & 8,1 \\
\hline & $37-45$ yaş & 38 & 11,9 \\
\hline & 46 - 59 yaş & 134 & 41,9 \\
\hline & 60 yaş ve üzeri & 122 & 38,1 \\
\hline \multirow[t]{2}{*}{ Hipertansiyon süresi } & $1-6 \mathrm{yll}$ & 191 & 59,7 \\
\hline & 7 yıl ve üzeri & 129 & 40,3 \\
\hline \multirow{2}{*}{$\begin{array}{l}\text { Tansiyonunuzu düzenli } \\
\text { ölçme durumu }\end{array}$} & Hayır & 128 & 40 \\
\hline & Evet & 192 & 60 \\
\hline \multirow[t]{2}{*}{ Evde tansiyon aleti varlığı } & Hayır & 120 & 37,5 \\
\hline & Evet & 200 & 62,5 \\
\hline \multirow{2}{*}{$\begin{array}{l}\text { Hipertansiyon hakkında } \\
\text { bilgi durumu }\end{array}$} & Hayır & 27 & 8,4 \\
\hline & Evet & 293 & 91,6 \\
\hline
\end{tabular}

*Birden fazla seçenek işaretlenmiştir. 
oluşturmaktadır. Bu hastaların \%65'inin (208) ailesinde de $(\% 8,4$ anne, $\% 7,8$ baba, $\% 8,4$ kardeş, $\% 7,2$ eş, $\% 4,4$ çocuk) hipertansiyon tanısı bulunmaktadır. Hastaların çoğu $(\% 61,9)$ tansiyonunun yüksek olduğunu ilk devlet hastanelerinde öğrenirken, \%91,6'sına (293) hastalıkları hakkında bilgi verilmiştir. En fazla bilgi veren bireylerin, doktorlar $(\% 40,9)$ olduğu söylenmiştir. Hastalar tansiyonlarını ölçme nedeni olarak ilk sıralara; baş ağrısı $(\% 23,1)$, tesadüfi ölçüm $(\% 21,9)$, çarpıntı $(\% 9,4)$ ve nefes darlığını $(\% 7,2)$ koymuşlardır.

Hastalar çoğunlukla $(\% 41,9)$ 46-59 yaşları arasında hastalıklarını öğrendiğini ve çoğunluğu $(\% 59,7)$ 1-6 yıldır bu hastalıkla yaşadığını ifade etmiştir. Hastaların \%62,5'inin (200) evinde tansiyon aleti bulunurken, \%60' tansiyonunu düzenli ölçtürmektedir. Tansiyonunu düzenli ölçtüremeyenler; ölçtürmeyi unuttuklarını $(\% 12,8)$, kendilerini iyi hissettiklerini $(\% 9,1)$, hastalığının çok ciddi olmadığını $(\% 6,9)$ belirtmişlerdir. Araştırmaya katılan hastaların $\% 65,9$ 'unun yemeklere başlamadan önce, yemeklere tuz attıklarını belirtmişlerdir. 320 hipertansiyon hastasının yemeklerindeki tuz miktarı $(\% 41,6)$ ve yağ miktarının $(\% 48,4)$ genellikle normal olduğunu söylemiştir. Hastaların \%49,7'si yağ çeşidi olarak, ayçiçek yağını tercih etmişlerdir. Yemek yeme hızları genellikle orta (30 dk.) hızda $(\% 60,6)$ olan bu hastaların çoğunun herhangi bir fiziksel aktivite yapmadığı $(\% 60)$ saptanmıştır. Hastaların büyük bir çoğunluğu $(\% 78,4)$ günde en az bir porsiyon taze meyve, sebze ve lifli gıdaları düzenli bir şekilde tüketirken, \%68,8'i günde 3 öğün yemek yerken, $\% 53,1^{\prime} i$ ara öğünde de yiyecek tüketmektedirler. Hastalar genelde etli yemekler $(\% 9,7)$ ve sebze yemekleri $(\% 6,6)$ tercih etmektedirler. Hastalar tansiyonlarını doğal yollarla dengelemek için daha çok, limondan $(\% 13,8)$ ve sarımsaktan $(\% 13,4)$ yararlanmaktadırlar.

Araştırmaya katılan 320 hastanın bazı alışkanlıkları incelendiğinde, 129 'unun $(\% 40,3)$ sigarayı hiç kullanmadığı, alkol kullanım oranının ise sadece $\% 1,9$ olduğu tespit edilmiştir. Bu hastaların \%37,5'i kahve tüketirken (\%17,2 Türk kahvesi, \%10,3 hazır sütlü kahve), \%94,7'si çay (\%92,5 kaçak çay) içmektedir. Ayrıca hastaların \%94,7'sinin de her gün çay içtiği saptanmıştır.

Tablo 3'te hastaların sosyo-demografik özelliklerine göre kan basıncı değerleri verilmiştir. Hastaların \%35,3'ünin sistolik kan basıncı değerleri 160 - 179 mm arasında iken, diyastolik kan basıncı değerleri ise, daha çok $89 \mathrm{~mm}$ ve altında $(\% 33,8)$ ve $110 \mathrm{~mm}$ ve üzerindedir $(\% 29,4)$. Araştırmaya katılan 320 hastanın ilaç kullanma ve bilgi
Tablo 3. Hastaların sosyo-demografik özelliklerine göre kan basıncı değerler

\begin{tabular}{|c|c|c|c|c|c|}
\hline \multicolumn{2}{|c|}{ Sistolik Ortanca } & \multicolumn{4}{|c|}{ Kan Basıncı Değerleri } \\
\hline & & & Diyastolik & & \\
\hline & & $p$ & Ortanca & $p$ & \\
\hline \multirow[t]{2}{*}{ Cinsiyeti } & Kadın & 157.77 & \multirow{2}{*}{0.554} & 154.19 & \multirow{2}{*}{0.220} \\
\hline & Erkek & 163.04 & & 166.36 & \\
\hline \multirow{2}{*}{$\begin{array}{l}\text { Çalışma } \\
\text { Durumu }\end{array}$} & Çalışmıyor & 148.35 & \multirow{2}{*}{0.001} & 148.59 & \multirow{2}{*}{0.001} \\
\hline & Çalışıyor & 183.07 & & 182.61 & \\
\hline \multirow[t]{4}{*}{ Yaşı } & 45’ten küçük & 199.94 & \multirow{4}{*}{0.009} & 208.66 & \multirow{4}{*}{0.007} \\
\hline & 45 - 59 arası & 167.61 & & 158.20 & \\
\hline & 60 - 74 arası & 155.75 & & 157.68 & \\
\hline & 75 ve üzeri & 132.59 & & 138.78 & \\
\hline \multirow{3}{*}{$\begin{array}{l}\text { Eğitim } \\
\text { Durumu }\end{array}$} & Okuryazar değil & 139.28 & \multirow{3}{*}{0.000} & 141.74 & \multirow{3}{*}{0.000} \\
\hline & Okuryazar & 166.27 & & 162.17 & \\
\hline & $\begin{array}{l}\text { İlköğretim mezunu } \\
\text { ve üzeri }\end{array}$ & 188.60 & & 188.15 & \\
\hline \multirow{3}{*}{$\begin{array}{l}\text { Gelir } \\
\text { Durumu }\end{array}$} & Geliri yok & 157.74 & \multirow{3}{*}{0.001} & 161.02 & \multirow{3}{*}{0.001} \\
\hline & 1 - $1300 \mathrm{TL}$ & 126.02 & & 120.47 & \\
\hline & 1300 TL üzeri & 217.51 & & 221.02 & \\
\hline
\end{tabular}

durumları incelendiğinde ise, kullanılan ilaçların genellikle Norvasc $(\% 15)$ ve Beloc Zok $(\% 7,5)$ olduğu saptanmıştır. Hastaların ilaçları kullanma süreleri genellikle 2 yıldan fazladır $(\% 31,2)$. Bu hastalar günde en az 1 defa $(\% 40,6)$ ilaç kullanırken, araştırmaya katılan hastaların çoğunun $(\% 50,9)$ kullandıkları ilaç(lar) hakkında bilgileri mevcuttur.

Kadınlarda sistolik kan basıncı ortancası 157,77 iken, erkeklerde 163,04'tür. Yine kadınlarda diyastolik kan basıncı ortancası 154,19 iken, erkeklerde 166,36'dır ve cinsiyetler arasındaki fark hem sistolikte hem de diyastolikte istatistiki olarak anlamsızdır ( $p>0.05)$. Çalışma durumu ile kan basıncı arasındaki ilişkiye bakıldığında çalışmayanlarda sistolik kan basıncı ortancası 148,35 iken, çalışanlarda ortanca 183,07 'dir ve aralarındaki fark anlamlıdır $(p<0.05)$. Hastaların yaşları ile kan basıncı değerleri karşılaştıııldığında; 45 yaşından küçüklerde sistolik kan basıncı ortancası 199,94 iken, 45-59 arası, 60-74 arası ve 75 ve üzeri olanlarda sırasılya; $167,61,155,75$ ve 132,59 'dur. Bu durum istatistiki olarak anlamlı bir fark vardır $(p<0.05)$. Okuryazar olmayanlarda sistolik kan basıncı ortancası 139,28 iken, okuryazarlarda 166,27, ilköğretim mezunu ve üzerinde ise 188,60 'dır. En yüksek oran ilköğretim mezunu ve üzerine ait iken aralarındaki fark istatistiki olarak da anlamlıdır $(p<0.05)$. 


\section{Tartışma}

Ülkemizde hipertansiyon sıklığını araştıran çalışmalar bölgesel veya daha geniş çapta olmak üzere 1960 'lı yıllardan bu yana yapılmaktadır. Ancak bu çalışmalar istenen ve beklenen düzeyde değildir. Özellikle bu çalışma Şanlıurfa'da hipertansiyon-hastalarının profilini tanımlamak konusunda en güncel ve kapsamlı bilgilere erişmek amacıyla gerçekleştirilmiştir.

Bu çalışmada hipertansiyon tanısı almış erkek hastalar $(\% 51,9$, Tablo 1) kadın hastalara göre daha fazladır. Literatürde ise bu sonuca ters olarak hipertansiyonun görülme sıklığı kadınlarda daha fazla olduğunu göstermektedir (13). Bu sonuç toplumsal cinsiyet faktörlerini düşündürmektedir. Çünkü Şanlıurfa bölgesinde erkeklerin kadınlara göre daha çok hastaneye başvurdukları, kadınların evden çıkmalarının daha zor olması ve kendisi ile ilgili problemleri geri plana atmaları yüzünden hipertansiyon olsa da tanı ve tedavi için kayıt altına alınmadıkları düşünülebilir.

Arıcı ve arkadaşlarının 2000 yılında yaptıkları 'Türk Hipertansiyon Prevalans' çalışmasında tüm grubun ortalama sistolik kan basıncı değeri $127.9 \pm 21.1 \mathrm{mmHg}$ çıkmıştır. Cihan'ın 2015 yılında Bitlis il merkezinde yaptığı çalışmada ortalama sistolik kan basıncı 126.29 \pm 17.86 mmHg, Özlem'in 2006 yılında Niğde'de yaptığı çalışmada ortalama sistolik kan basıncı 131.51 \pm 0.76 mmHg, Murat'ın 2008 yılında Afyonkarahisar ilinde yaptığı çalışmada ise ortalama kan basıncı değeri $136.4 \pm 12.0 \mathrm{mmHg}$ çıkmıştır (14-16). Oysa bu çalışmada hastaların ortalama sistolik kan basıncı değerinin yüksek $(153.42 \pm 24,15 \mathrm{mmHg})$ çıkması önemli bir sonuç olduğu ve hemen müdahale edilmesi gereken bir durum olduğu söylenebilir. Çünkü kan basıncı değeri yükseldikçe kişinin tedavisinin daha zor ve komplikasyonları fazla olacaktır. Bu durum kişinin bütün yaşam kalitesini olumsuz etkileyecektir. Sistolik kan basıncı ortalama değeri, Arıcı ve arkadaşlarının yaptığı çalışmada, kadınlarda daha yüksek bulunmuştur. Bu çalışmada ise erkeklerde daha yüksek bulunmuştur (Tablo 3, p>0,05). Bu durum erkeklerin kadınlara göre daha fazla stres yaşadıklarını düşündürebilir. Çalışma durumuna göre hastaların sistolik kan basıncı değerlerine bakıldığında; çalışanlarda çalışmayanlara göre sistolik kan basıncı değerinin (çalışmayanlarda $148.35 \mathrm{mmHg}$, çalışanlarda 183.07 mmHg, Tablo 3) daha yüksek sonuç çıkması çalışanların daha fazla stres yaşadığını destekleyebilir $(p<0.05)$.

Bu çalışmadan çıkan ve dikkate değer bir başka sonuç ise, yaş arttıkça sistolik ve diyastolik kan basıncı ortancalarının düşmesidir. Oysa literatüre göre yaş arttıkça kan basıncı değerlerinde artış eğilimi vardır. Özlem'in 2006 yılında Niğde'de yaptığı çalışmada; yaş arttıkça ortalama sistolik kan basıncı artış göstermektedir (15). Yine Nagahan'ın 2009 yılında Konya ilinde yaptığı çalışmada ortalama sistolik kan basıncı yaş arttıkça artmıştır (17). Bu sonuçlara göre, hipertansiyona yönelik hizmetler acilen ele alınmalı ve hemşireler özellikle yetişkin grubunu öncelik kabul edip, bütün risk faktörlerine yönelik hizmetleri ele almalıdır.

Sigara içme durumuna bakıldığında araştırmaya alınan hastaların \%59,7'si sigarayı önceden kullanmış ya da halen kullanmaktadır. Sigara kullananlarda hipertansiyon görülme sıklığının daha yüksek olduğu yapılan bazı çalışmalar ile tespit edilmiştir (18). Hastalarımızda; hipertansiyon hastası olmalarına rağmen sigara içme oranın yüksek olması sigaranın tek başına tansiyon etkeni olmamasından kaynaklanabilir. Toplum olarak da sigara içme oranımızın yüksek olması hastaların bu konuyu göz ardı etmelerine neden olabilir. Yapılan bazı araştırmalarda sigara kullanmayan bireylerin tedaviye uyum puan ortalamalarının sigara kullananlardan daha yüksek olduğunu göstermiştir. Nitekim yapılan araştırmalar sigara içmeyen bireylerin tedaviye uyum düzeylerinin içenlerden daha yüksek olduğunu bildirmiştir $(19,20)$.

Çalışmamıza katılan hastaların \%6,6'sı çok tuzlu, \%8,4'ü çok yağlı ve \%37,5'i kahve içmektedir (Tablo 4). Yapılan araştırmalarda esansiyel hipertansiyonun nedenleri birçok etkene bağlıdır. Bu etkenler; yaş, aşırı tuz kullanımı, düşük potasyum alımı, sedanter yaşam, sigara, alkol ve kafein kullanımı, obezite, ateroskleroz, stres, genetik yatkınlık olarak sıralanabilir $(21,22)$. Yapılan araştırmalar beslenme alışkanlıklarını düzenlemenin, fiziksel egzersiz yapmanın, sigarayı bırakmanın ve alkol tüketimini sınırlandırmanın yaşam kalitesini arttırdığını bildirmiştir. Bu faktörlerin yaşam kalitesi üzerindeki etkisinin kan basıncının düşmesiyle ilişkili olduğu ileri sürülmektedir $(23,24)$.

Çalışmaya alınan hastaların gelir durumu yüksek olanlarda kan basıncı değerleri de diğer gruplara oranla yüksek bulunmuştur(Tablo 3). Elazığ'da hipertansiyon hastaları üzerinde yapılan bir çalışmada gelir durumu 3000 TL'nin üzerinde olanlarda fiziksel ve mental sağlık puan ortalamaları, 3000 TL'nin altında olanlara göre daha düşük bulunmuştur (25). Gelir durumu yüksek olanlar genelde masa başı, daha az aktivite ve sedanter yaşamı kapsadığı için bu kişiler kan basıncı değerlerinin daha fazla olabileceği düşünülmektedir. Aynı şekilde çalışan kişilerde çalışmayanlar göre kan basıncı değerleri daha yüksek 
bulunmuştur (Tablo 3). Çalışma ortamından kaynaklanan stres faktörünün bu konuda etkili olduğu düşünülmektedir. Ancak Cihan'ın Bitlis'te yaptığı çalışmada, çalışmayanlarda yüksek kan basınçlı olanların oranı daha yüksek bulunmuştur (14).

Araştırmada hastaların tansiyonlarını ölçtürmeme ve/ veya kontrollerini yaptırmama nedenlerinin sırasıyla; unutma (\%12.8), kendini iyi hissetme (\%9.1), hastalığının çok ciddi olmadığını düşünme (\%6.9), işlerinin çok yoğun olduğunu düşünme (\%4.7), maddi sıkıntılar (\%4.1) ve ulaşım sorunları (\%2.5) yüzünden olduğu saptanmıştır. Bu araştırma bulgusuna benzer olarak, Özbayram'ın 2008 yılında yaptığı araştırmada kontrole gelmede uyumsuzluk nedenleri sırasıyla; iş yoğunluğu, kendini iyi hissetme, ulaşım sorunları ve hastalığı önemsememe olarak sıralanmıştır (26). Ayrıca, Gülden'in 2012 yılında Elazığ'da yaptığı çalışmada bu oranlar; ulaşım sorunu yaşama (\%23.6), kendini iyi hissetme (\%8.6), hastalığının çok ciddi olmadığını düşünme (\%5.5), kontrollerini unutma (\%4.1) ve iş yoğunluğundan dolayı gidememe (\%2.3) olarak belirlenmiştir (86). Hastaların hastalık konusunda farkındalıklarının arttırılmasının ve aile üyelerinin hastalık konusunda bilgilendirilmesinin ve efektif şekilde tedavi sürecine katılmalarının bu tür olumsuz etmenleri ortadan kaldıracağı ifade edilmektedir (27).

$\mathrm{Bu}$ araştırmada geleneksel yöntem kullananların oranı \%65.9'dur. Bu alternatif yöntemler; limon (\%13.8), sarımsak (\%13.4), dinlenme (\%7.2), bitkisel karışımlar (\%2.5) ve maydanoz (\%1.2) olarak belirlenmiştir. Ergün, Yıldırım ve Alparslan'ın 2002 yılında yaptıkları araştırmada, alternatif tedavi yöntemlerinin; tuzsuz diyet uygulama, kilo verme, uygun egzersiz ve bitkisel ürün kullanımı olduğu bulunmuştur (28). Yine Gülden'in 2012 yılında Elazığ'da yaptığı çalışmada bu oran, \%45.5'tir. Hastaların kullandığı başlıca alternatif yöntemler ise; limon (\%30.9), sarımsak (\%12.7) ve bitkisel karışımlar (\%1.8) olduğu saptanmıştır (25). Burada alternatif tedavi yönteminin ilaç tedavisiyle birlikte sürdürülmesinin önemi vurgulanmalıdır.
Anti-hipertansif tedavinin her yönüyle bir bütün olarak ele alınması, tedaviden yüksek düzeyde faydanın elde edilmesini sağlayacaktır.

\section{Sonuç ve öneriler}

Bu araştırmada, şu sonuçlara ulaşılmıştır.

- Hastaların \%65'inin ailesinde de hipertansiyon tanısı bulunmaktadır.

- Hastaların \%35,3'ünün sistolik kan basıncı değerleri 160 - 179 mm arasında iken, diyastolik kan basıncı değerleri ise, daha çok $110 \mathrm{~mm}$ ve üzerindedir $(\% 29,4)$.

- Bu Çalışma sonuçlarına göre, çalışan kişilerde hem sistolik hem diyastolik kan basıncının daha yüksek olduğu tespit edilmiştir.

- Hastaların yaşlarına bakıldığında 45 yaş ve altındaki bireylerin sistolik ve diyastolik kan basıncı değerlerinin diğer yaş gruplarına oranla daha yüksek olduğu görülmüştür.

Bu sonuçlar doğrultusunda, hipertansiyon hastalığının zararlarını en aza indirgemek için;

- Hipertansiyon hastalığı konusunda daha fazla araştırma yapılmalı ve araştırma sonuçları HT tanısı almış hasta bakımına yansıtılmalı,

- Tüm toplum özellikle de 45 yaş altı bireyler rutin tansiyon kontrolü yapmalı

- Beslenmede tuz alınımı kısıtlanmalı ve tansiyon ölçümlerinin düzenli yapılması gibi yaşam tarzı değişiklikleri ve ilaç kullanımı konusunda eğitim verilmeli,

- Özellikle çalışan kişiler, hareketsiz yaşam, beslenme şekilleri ve stres faktörlerine dikkat etmeli,

- Bir sağlık profesyoneli olan hemşirelerin HT eğitimi almaları; gerekli eğitim sağlandıktan sonra; HT merkezli hemşirelik uygulamalarını geliştirmeleri, sağlıklı ve/ veya hasta bireyleri tamamlayıc ve destekleyici tedavileri etkin ve doğru şekilde kullanmaları konusunda yönlendirilmelidir. 


\section{Kaynaklar}

1. Erkoç Y, Yardım N. Türkiye'de Bulaşııı Olmayan Hastalıklar ve Risk Faktörleri ile Mücadele Politikaları. Ankara. Anıl Matbaası. 2011;18.

2. Dilek Güven Ş, Nimet K. Hipertansiyonlu Hastalara Uygulanan Ayak Refleksolojinin Kan Basıncı, Kolesterol Düzeyleri ve Yaşam Kalitesine Etkisi. Hemşirelikte Araştırma Geliştirme Dergisi. 2013; 15: 56-67.

3. T.C. Sağlık Bakanlığı. Türkiye Hastalık Yükü Çalışması. 2004.

4. Gök H. Klinik Kardiyoloji. 2. Baskı. Nobel Tıp Kitapevleri Ltd. Şti. İstanbul. 2002; 619-59.

5. Kaplan NM. Management Of Hypertensive Patients With Multiple Cardiovascular Risk Factors. American Journal Of Hypertension. 2001; 14: 221-24. [CrossRef]

6. Vos LE, Oren A, Uiterwaal C, Gorissen WH, Grobbee DE, Bots ML. Adolescent Blood Pressure And Blood Pressure Tracking Into Young Adulthood Are Related To Subclinical Atherosclerosis: The Atherosclerosis Risk in Young Adults (Arya) Study. American Journal of Hypertension. 2003; 16:549-55.

7. Kearney PM, Whelton M, Reynolds K, Muntner P, Et Al. Global Burden of Hypertension: Analysis of Worldwide Data. Lancet. 2005;365:21723. [CrossRef]

8. Altun B, Arici M, Nergizoğlu G, Derici U, Karatan O, Turgan, C, et al. Prevalence, Awareness, Treatment And Control of Hypertension in Turkey in 2003. J Hypertens. 2005; 23:1817-23.

9. http://www.turkhipertansiyon.org/prevelans_calismasi_2.php Erişim Tarihi: 02.05.2019

10. T.C. Sağlık Bakanlığı Halk Sağlığı Kurumu. Türkiye Kronik Hastalıklar Ve Risk Faktörleri Sıkığı Çalışması. (Edit). Ünal B, Ergör G. Anıl Matbaa Ltd. Şti. Ankara. 2013

11. Aram VC, George L, et al. The Seventh Report of The Joint National Committee on Prevention, Detection, Evaluation, and Treatment of High Blood Pressure. The Jnc 7 Report. JAMA. 2003:21;289:2560-72. [CrossRef]

12. Yazıcıoğlu Y, Erdoğan S. Spss Uygulamalı Bilimsel Araştırma Yöntemleri. Detay Yayıncılık. Ankara. 2004:50.

13. Türk Hipertansiyon ve Böbrek Hastalıkları Derneği. Türk Hipertansiyon Prevalans Çalışması. Patent 2, 2012.

14. Önen C. Bitlis İı Merkezindeki Yetişkinlerde Hipertansiyon Sıklığı ve Yöresel Beslenmeyle Illişkisi. Halk Sağlığı Anabilim Dalı, Doktora Tezi. Bitlis. 2015: 30.
15. Boylu Ö. Niğde İli Kemerhisar Kasabasındaki 40 Yaş ve Üzeri Popülasyonda Hipertansiyon Prevalansı ve Farkındalık Durumu. Halk Sağlığı Anabilim Dalı Yüksek Lisans Tezi. 2006: 42.

16. Özkan M. Afyonkarahisar İli Dinar İlçesi 40 Yaş ve Üzeri Popülasyonda Hipertansiyon Prevalansı ve İlişkili Faktörlerin Araştırılması. İç Hastalıkları Hemşireliği Anabilim Dalı. Yüksek Lisans Tezi. 2008: 60.

17. Parabaş N. Konya İli Hadim İlçe Merkezindeki 40 Yaş ve Üzeri Popülasyonda Hipertansiyon Prevalansı ve Farkındalık Durumu. Halk Sağlığı Anabilim Dalı Yüksek Lisans Tezi. Konya. 2009: 41.

18. Hacıalioğlu N, Günaksın A, İnandı T. Gümüşhane İli Torul Merkez Sağlık Ocağı Bölgesi 30 Yaş ve Üzeri Nüfusta Hipertansiyon Prevalansı ve İlgili Etmenler. T. Klin. Tıp Bilimleri. 1999; 19:200-208.

19. Kyngas $\mathrm{H}$, Lahdenpera T. Compliance of Patients with Hypertension and Associated Factors. J Adv Nurs. 1999;29:832-9.

20. Fodor Gj, Kotrec M, Bacskai K. Is Interview a Reliable Method to Verify the Compliance with Antihypertensive Therapy? An International Central-European Study. J Hypertens, 2005; 23: 1261-6

21. Carretero O, Oparil S. Essential Hypertension Part I: Definition And Etiology. Circulation. 2000; 101: 329-35.

22. Ramzi S, Cotran, Stanley L. Robbins, Vinay Kumar. Temel Patoloji Basic Pathology. 7. Baskı; Nobel Tıp Kitabevleri. 2002: 294-8.

23. Banegas JR, Guallar-Castillon P, Rodriguez-Artalejo F. Association Between Awareness, Treatment, and Control of Hypertension, and Quality of Life Among Older Adults In Spain. Am J Hypertens. 2006;19: 686-93. [CrossRef]

24. Çelik B. Hipertansiyonlu Hastalarda Yaşam Kalitesi İle İlişkili Faktörlerin Araştırılması. Afyonkocatepe Üniversitesi. Sağlık Bilimleri Enstitüsü. Yüksek Lisans Tezi. Afyon. 2008.

25. İçyerioğlu G. Hipertansiyon Hastalarının Tedaviye Uyumu ve Yaşam Kalitesi. Fırat Üniversitesi. Sağlık Bilimleri Enstitüsü. Yüksek Lisans Tezi. Elazığ. 2012.

26. Özbayram A. Yeni Hipertansiyon Tanısı Almış Hastalarda Tedavi Uyumu ve Etkileyen Faktörler. Marmara Üniversitesi. Yüksek Lisans Tezi. Sağlık Bilimleri Enstitüsü. İstanbul. 2008.

27. Akgöz C. Hipertansiyon Hastalarında Antihipertansif Tedaviye Uyumun Değerlendirilmesi. İstanbul Üniversitesi. Cerrahpaşa Tıp Fakültesi. Uzmanlık Tezi. İstanbul. 2008.

28. Ergün UGÖ, Yıldırım MY, Alparslan N. Esansiyel Hipertansiyon Hastalarında Sosyo-Ekonomik Düzey Farklılığı ve Illaç Uyuncu. Türk Aile Hekimliği Dergisi. 2002; 6: 165-71. 